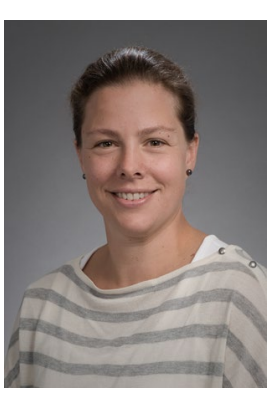

\title{
Hey man
}

\author{
Men have a role to play as well in leveling the playing field for women scientists. This includes \\ creating inclusive environments and accepting women as equal partners in the pursuit \\ of science.
}

Credit: Marion Pepper

T here is no lack of evidence on the abject discrimination and offenses that women in science experience ${ }^{1}$. This was the reality that I had prepared myself for in a career in biomedical research, a field that is dominated by men. And while like many other women in immunology I have experienced egregious incidences of blatant sexism and harassment, these have been few and far between. Instead, for the majority of my career I have been fortunate to find incredible male mentors and colleagues who have acted as staunch supporters and advocates. Yet despite this, my experience in the field of biomedical research has also been overshadowed by an insidious sensation of not quite fitting in, of never really being included in the maledominated world that we women traverse as often pointed out to us by the portraits in the hallowed halls of our institutions.

As much as I and others would prefer to ignore the reality, a sex classification still exists in the biomedical research world that creates a sense of 'other' for women scientists. This is, of course, obvious in so many contexts beyond research. Any time one group has dominated a position of power for so long, a different status for any other group that may want to be involved is automatically created. This manifests itself in all too common scenarios in science: the 'old boys club' hanging out at the bar with the journal editors, promoting their friends as speakers at conferences or in seminar series, supporting their buddies as coprincipal investigators on grants, or advocating for grants to be funded during study sections. While it may not be obvious to the person in power, it is palpable when you are looking at it from the other side. This not only creates an unlevel playing field but also erodes a woman's sense of belonging in deleterious, nebulous ways that inevitably lead to self-doubt. These subtle, unspoken rules permit women entry into this male-dominated world as colleagues, but never truly proffer equal participation or inclusion into this fraternity. This is why only the men in our field, through their awareness and acceptance that these encounters deeply affect women scientists' sense of belonging, can make efforts to include women and make this change happen.

I entered the field of immunology because I truly love trying to understand the intricacies of the immune system. Curiosity about how the immune system works keeps me awake at night. I can't wait to see data from my lab that fill in even the smallest gap in our knowledge. I can't imagine studying anything else. When I first entered the field, I had confidence that, professionally, female scientists would be accepted on the basis of data, promoted on the basis of hard work and scientific acumen and embraced as colleagues because of their desire and ability to advance the field. I naively believed that, whatever persona you threw at the system, it could catch, embrace and provide room for whoever you were. Unfortunately, we are not there yet. Rarely have I heard women scientists be described in terms that are often used for men. How often have you heard a woman researcher described as a "rock star" or as doing "game-changing research"? Instead, the focus is often on a woman's personality or appearance and how it distracts from the science. One recent transgression occurred to a brilliant, awardwinning scientist with a publication record that any scientist, male or female, would covet. After her seminar, a male colleague pulled her aside to ask her if she were "for real" or if she were just "up there prancing on stage." Prancing?! And for the record, not that it matters if she were, but she is not a prancer. He actually asked her to somehow prove to him that she was "the real deal" because he just could not wrap his head around the fact that she didn't act in a way that he found acceptable for a scientist because she spoke with enthusiasm and charm. I can't imagine this being asked of a male colleague, although maybe men don't convey these experiences to me.

So, here is my request to my male colleagues, many of whom I love dearly and who perhaps are not even aware that this is happening. Please recognize that you are complicit in this system. Please allow women to be scientists in their own image - behaving as themselves, rather than following expected norms based on previous male stereotypes. And please, strive to include female scientists in collaborations, publications, programs at meetings, or the pool of grants that you fight for, in the same way that you do for your male colleagues. I am not advocating for men to always have women around. Yet, when there are professional outcomes to these interactions, at least consider bringing along your women colleagues. I know some of you understand this already and are making important changes that are already creating inclusive environments. But if you are not, please try. And finally, we all need to pay attention to inadvertently making anyone feel unworthy of being part of a field because of who they are, when their science is what should matter most. If there is a field that can create an inclusive environment for everyone, it is the forward thinking, creative, collegial field of immunology that I am so very proud to be a part of.

\section{Marion Pepper (iD}

University of Washington School of Medicine, Department of Immunology, Seattle, WA, USA. e-mail:mpepper@uw.edu

Published online: 24 February 2020

https://doi.org/10.1038/s41590-020-0619-3

References

1. Klein, R. S. et al. Nat. Immunol. 18, 475-478 (2017).

Competing interests

The author declares no competing interests. 